\title{
Interactional Resistance During Black Lives Matter Protests: The Political Stakes of Rebelling Against the Public Order
}

Chloe Haimson

\begin{abstract}
Note: This is an unedited pre-print of a forthcoming article in Mobilization. This version has not been copy-edited.

Drawing from ethnographic research, this study examines how interactions between protesters and police unfold at Black Lives Matter demonstrations in two cities with distinct policing regimes. I argue that protesters consciously resist the terms of engagement set by police in an effort to demonstrate their opposition to police violence and racism, as well as demonstrate that communities can police themselves, while also seeking to avoid arrest or police violence. I call this protesters' interactional resistance. This resistance is predicated on protesters pushing the boundaries of rules of engagement while using their structural knowledge of the situation and likely police responses. In contrast with prior research, a focus on interactional resistance emphasizes the actions and decisions of protesters, not just the police. It also shows how protesters manage to enact resistance even when they are trying to avoid arrest. Overall, these microinteractions both point to and shape the structures of repression.
\end{abstract}


Between 2012 and 2016, the United States witnessed an explosion of protest in response to police violence and racial injustice, known nationally as the Black Lives Matter movement. Identified by media outlets as the civil rights movement of this century, it has garnered national attention. Although media attention has subsided, the movement is still ongoing.

All social movements are concerned with police presence at protests. Protesters often fear that police will suppress their activities, be violent towards individuals participating in the movement, or incite violence in the crowd. In contrast, police view their own presence as essential to upholding the peace and instilling order.

Black Lives Matter movements are different from most current protest movements because they are directly organized in response to police violence and state surveillance. Recent research suggests that police are more likely to have a presence at protests where they are the target of such protests, as well as more likely to make arrests and use force against protesters. Further, protests against police initiated by racial minority groups are even more likely to have a police presence than those initiated by other racial groups (Reynolds-Stenson 2017; Davenport, Soule, and Armstrong 2011).

Building on previous scholarship that often focuses on protest-specific contexts that influence whether police repression will arise and the ways that repression has transformed over time, I argue that protesters are actively engaged in anticipating police responses to their behavior and intentionally build these judgments into their actions. All protesters make such calculations. However, what is unique about Black Lives Matter protests is that through dramaturgy tactics, certain interactional moments or the potential for such moments between protesters and police become critical for showcasing the 
movements' overarching goal of showing that communities are capable of policing themselves. Protesters' tactics and balancing act decisions become central to convincingly demonstrating this claim.

In a departure from most research on protest policing, I show not just how police repression is enacted but how protesters' tactics are shaped by expectations they hold for police, even when the police are not physically present at a protest. Previous literature examines how police manage to control movement protests even before they begin, as well as the civil disobedience tactics that protesters used in the Civil Rights Movement and subsequent movements (Morris 1984; Noakes, Klocke, and Gillham 2005). In contrast, this research more narrowly hones in on key interactional moments that happen during demonstrations. Protesters I observed were not innovating new tactics; rather they were engaged in pushing the edge of the boundaries of interactions and expressing their defiance in relatively minor ways. I show how protesters use their local cultural knowledge of how the police can be expected to respond during these interactions in an effort to minimize the possibility of arrest while maximizing disruption.

Micro-sociologists doing conversational analysis use the term interactional resistance in a non-political way to refer to peoples' opposition to situations in which others attempt to make them comply with requests - whether that be patients in response to doctors, students in response to tutors, or interviewees in response to journalists (Benwell and Stokoe 2002; Clayman 2001; Monzoni, Duncan, Grünewald, and Reuber 2011).

I use the term in this study to describe the deeply political ways that protesters enact their opposition to police presence at demonstrations. Jocelyn Hollander and Rachel 
Einwohner (2004) discuss the varied ways in which the term "resistance" is used, stress its interactional nature, and typologize resistance with the following scheme: Is the act intended as resistance by the actor? Is it recognized as resistance by the target? By other observers? I observed what Hollander and Einwohner (2004) call “overt resistance,” actions that were intended by the protesters as resistance and seen by targets and observers as resistance. In some cases the police were not present, and the resistance could be categorized as covert in their scheme (not recognized by the target, but intended and perceived as resistance by observers.)

I show how protesters can consciously reject the terms of engagement and interaction set by police and other authorities as a means to demonstrating their resistance to racism and police brutality. In traditional civil disobedience, those who break the law for a just cause expect to be arrested and punished. I observed activists who sought to break the law, cause disruption, and express dissent without getting arrested. I use the term "interactional resistance" for this dramaturgical performance in which activists seek to demonstrate their resistance to police's terms of engagement while minimizing the risk of a serious altercation with the police.

Research documents how police strategies concerning managing protests has changed over time since the 1960s from escalated force to strategic incapacitation in response to varying protest tactics, as well as how protests targeting police are more likely to have increased surveillance by law enforcement (McPhail, Schweingruber, and McCarthy 1998; Noakes, Klocke, and Gillham 2005; Reynolds-Stenson 2017). Scholars have also paid attention to how protesters use various tactics, particularly those performative in nature to leverage power and manage movement outsiders' perceptions 
of them (Benford and Hunt 1992; Goffman 1959; Snow 1979). In this paper, through ethnographic observations, I explore how Black Lives Matter protests against police violence in two cities contend with these protest policing trends, use dramaturgical tactics to make movement claims, and in contrast with past protest movements, do so while overwhelmingly trying to avoid arrest or a serious altercation with police. I find that protesters' interactions with police at protests and their anticipations of police responses to their confrontational tactics become central to local Black Lives Matter movements for demonstrating their claim that communities can police themselves. However, this is a complex task to achieve. How does one maximize disruption while minimizing the possibility of arrest? In a departure from prior research on this topic, I find that this question is more contingent on local policing norms that vary by place, than on protest tactics.

\section{The Situated History of Protest Policing}

\section{Black Lives Matter}

In August 2014, in Ferguson, Missouri, Darren Wilson, a white police officer, shot twelve bullets at Michael Brown, an unarmed Black teen, killing him. After the shooting of Brown, the first protesters were young, Black Ferguson community members outraged that it had taken police four hours to pick up his body from the middle of the street. The public watched the protests in Ferguson as broadcasted by media, bringing to mind a powerful legacy of social movements - the Civil Rights Movement and race rebellions of the sixties. The Ferguson protests continued for months and organizing continues today. Perhaps even more significantly, the demonstrations spread across the country. A national movement had begun to take shape. 
The term "Black Lives Matter" first began as a social media hash tag by three Black queer women organizers, Patrisse Cullors, Alicia Garza and Opal Tometi, after George Zimmerman was acquitted for shooting Trayvon Martin in 2013. The phrase spread to hundreds of political demonstrations across the country, developing as a symbol for the country's devaluing of Black lives in the face of gross disparities in police killings and prison sentencing.

Between 2012-2016, protesters gathered and organized across the country in response to other shootings of unarmed Black men, women, and transgender individuals. They were part of a larger movement demanding a radical transformation in the United States' criminal justice system, a movement fighting to end police brutality, mass incarceration, and the devaluation of Black lives. Simply put, Black Lives Matter is a movement demanding that the country see Black people as humans, deserving of the same rights and treatment as white Americans.

\section{The History of Policing at Protests in the U.S.}

In order to examine present day interactional dynamics between protesters and police, it is critical to understand how police have historically reacted towards protesters and police's orientation toward the use of force and extent of communication with protesters. Clark McPhail, David Schweingruber, and John McCarthy (1998) use two terms to describe police strategies in overseeing protesters: escalated force and negotiated management. More recently, the term strategic incapacitation has been used to describe current day practices (Noakes, Klocke, and Gillham 2005). 
During the 1960s, police in the United States used escalated force to control protesters, which often led to conflicts in the streets. McPhail, Schweingruber, and McCarthy (1998) characterize this style of protest policing as law enforcement's opposition towards people's first amendment right to protest or participate in any kind of disruption. During this era, there was no communication between the two parties and police often relied on forceful, violent arrests as a way to manage protesters, even during moments when they had not broken the law. A number of Supreme Court decisions and national commissions during the late sixties and seventies paved the way for the rise of negotiated management style of policing, a replacement of escalated force. These historical events occurred in light of the race rebellions of the sixties, which grew out of a deep dissatisfaction with the police's treatment of Black people.

Negotiated management allows for protesters and police to consult with one another and reach a consensus regarding the rules of a demonstration. It is classified as a style whereby police uphold peoples' right to demonstrate, as well as engage in a lack of enforcement of the law, allowing for some degree of disruption by protesters. Protesters and police can speak more openly together and police refrain from use of force (McPhail, Schweingruber, and McCarthy 1998). Since the rise of negotiated management in the 1960s, Jennifer Earl, Sarah Soule, and John McCarthy (2003), Mike King (2013), and Patrick Rafail, Sarah Soule, and John McCarthy (2012) argue that police use of force at protests has declined. However, there is debate as to what this trend means for our notions regarding the existence of contemporary forms of repression. For instance, Jennifer Earl (2005) problematizes the conception that arrests of protesters are necessarily less harmful than violence against them, as a host of new obstacles can 
emerge for protesters once they are arrested by the police and enter into jail. Additionally, other forms of repression of social movement activities persist today including arrest, surveillance, and channeling (Earl 2003; Earl 2005; Gillham, Edwards, and Noakes 2013).

Protesters are often hesitant to accept the police's terms of negotiation and research seems to suggest that they have good reason to fear the police's role. Although communication increases under negotiated management, police and protesters' interests do not necessarily align. Protesters often fear that police surveillance will result in the suppression of their movement's activities. They want significant turnout for their protests in order to display sizeable support for their causes. Past research suggests that the police's orientation can be in direct opposition to these aims. For example, Donatella Della Porta and Herbert Reiter (1998) note that the "large scale collection of information" is part of how police oversaw protests during the 1990s, and Patrick Gillham and John Noakes (2007) argue that strategies used by police through negotiated management are purposefully meant to inhibit protests from growing in size. In addition, negotiated management makes even large protests not significantly disruptive, which may reduce their intended impact.

Previous scholarship on this topic focuses on the numerous contexts that influence whether police choose to enact repressive tactics. Repression has not disappeared, rather its nature has evolved over time and police are more selective than they once were about who bears its brunt. For instance, in recent years, scholars have suggested that various aspects of demonstrations matter for determining whether police repression will arise during a protest, including indicators of the race and social status of participants, as well 
as the tactics used by protesters (Davenport, Soule, and Armstrong 2011; Earl, Soule, and McCarthy 2003; Soule and Davenport 2009).

Other scholars have complicated our notions regarding the dominant negotiated management style of policing of protests. They advance the argument that in response to the terrorist attacks of September 11 a new police repression strategy of protests emerged and is on the rise, resulting in decreased levels of trust and communication between police and protesters. John Noakes, Brian Klocke, and Patrick Gillham (2005) and Patrick Gillham, Bob Edwards, and John Noakes (2013) argue that transgressive protesters during the Washington D.C. anti-war protests in 2001 and New York City Occupy Wallstreet protests in 2011 were met with policing that they characterize as strategic incapacitation in contrast with negotiated management. This style refers to police's increased reliance on surveillance of activist groups, proactive policing, and the regulation of space in controlling protests. Ethnographic research by Noakes, Klocke, and Gillham (2005) shows that transgressive protesters in their study were more likely to experience spatial control of their activities by police than other types of protest groups. Their research suggests that transgressive protesters in turn became more indignant as they came under greater physical control and scrutiny.

These prior cases, although very valuable for thinking about police behavior and descriptions of protest activity, mainly detail how repression is enacted and not how activists build their calculations and anticipations about police into their movement activities. Additionally, in all of these cases, police are present. Interactional resistance, which I use in this paper to describe a key strategy of Black Lives Matter protests, shifts 
the focus and puts it on activists to explain how they contend with the possibility of repression and spatial control of their activities at protests even when police are absent.

Research on anti-war protests in D.C. in 2001 in anticipation of a military invasion of Afghanistan shows that interactions between police and protesters became most contentious when police enacted control over the space protesters were permitted to demonstrate in (Noakes, Klocke, and Gillham 2005). Thus, if we were to apply an interactional resistance frame to the D.C. protests, we may be interested in examining the bounds of activists' resistance even in the moments when police were not present, how activists' tactics shifted depending on their expectations for police, as well as why breaching certain spatial bounds during protests held important meanings for protesters given their specific movement objectives.

Additionally, in a departure from prior research and perhaps counterintuitive, I observed that protesters in my study in Big City were met with strategic incapacitation by police even when they were not being transgressive in their tactics; while protesters in College City experienced tactics closer to negotiated management when they were being more transgressive in their approach. Thus, by making crude dichotomies between police tactics as well as protest tactics in prior research, sociologists run the risk of oversimplifying police and protester relations. My finding indicates that police response to protesters may be more contingent on local control norms than protest tactics.

Protesters' intended interactional resistance was a critical component of the local Black Lives Matter movements I observed. I believe interactional resistance occurs in other movements as well, although it would take different forms in different movements. In the interactional resistance I observed, protesters aimed to demonstrate that 
communities can be autonomous, self-policing bodies through their purposeful, tactical choice to engage in interactional resistance with the police. The act of successfully carrying out interactional resistance without risking one's freedom is predicated on a type of complex, protester knowledge.

\section{Negotiating Protest Tactics and Relationships with Opponents}

Examining protester interactions with the police in Black Lives Matter movements not only allows us to better understand protesters' tactics, but also the ways in which movements evolve on the ground to meet objectives in fighting against police control and misconduct.

Social movement scholars have drawn attention to the dramaturgical aspects of collective action tactics as a key strategy employed by movements in order to carefully manage the impressions that others form of them for the purpose of achieving certain aims and establishing power (Benford and Hunt 1992; Goffman 1959; Snow 1979). The performative aspects of the Black Lives Matter protests in their relations with police at protests were a key tactic for demonstrating local movements' aims. Protesters engaged in minor forms of defiance to show both that communities are capable of policing themselves and that they should have the power to set the terms of engagement with police inside and outside of the sphere of protests. They did this by pushing the boundaries of their interactions while trying to minimize the possibility for arrest. Through their interactional resistance they showed the public that protests can be peaceful and that protest organizers can maintain control without needing police intervention. 
Similarly, Donatella Della Porta and Mario Diani (2006) discuss how protesters and police become acquainted with each other's street-level choreography so an iterative "learning process" involving both sets of actors emerges during the course of a protest (185) as each group makes tactical choices and subsequent adjustments to their behavior in response to the actions of the other group. Both groups' actions impact the others for the course of the protest and the building of a social movement (Bloom and Frampton forthcoming).

Analyzing protesters' tactics is essential since they matter for the course of collective action (McCammon, Chaudhuri, Hewitt, Muse, Newman, Smith, Terrell 2008; Morris 1993; Uba 2005). Past social movement scholarship has examined protesters’ tactical choices and the role of intentionality in these choices (Taylor and Van Dyke 2004). Extending this literature, this study considers the role of intentionality in how protesters anticipate repression and then choose to respond to it.

When they choose to engage in disruptive tactics, protesters are simultaneously seeking to appear legitimate and thus minimize costs such as loss of support or repression by authorities and behaving disruptively enough that they place pressure on opponents (Braunstein 2018; Larson 2013; Meyer 2007; Wang and Piazza 2016). David Meyer (2007) writes, “Activists make choices cognizant of the likley responses of supporters, authorities, and bystanders and pay particular attention to how their actions will be portrayed to those audiences" (125). These interactional moments and balancing act decisions are important for understanding how protesters try to make an impact with their resistance without going too far as to lose legitimacy or freedom. 
Some prior social movements have intentionally sought arrest as part of their tactics. As described in Aldon Morris's $(1984 ; 1993)$ work, protesters' calculations about the expected responses of police and other authorities were central in the Civil Rights Movement's tactical planning. Sit-ins and freedom rides were forms of civil disobedience strategies that directly challenged the wide-spread segregation laws. Other forms of protest that occurred during this time were designed to incite a crisis through over-filling the local jails with protester arrestees. For example, the Birmingham campaign intentionally filled local jails with young protesters. Protesters risked both arrest and police violence during the course of demonstrating against the oppressive, segregated state. The Albany campaign preceded Birmingham, which failed to achieve a victory despite heightened protests and mass arrests because the police chief avoided overt violence and planned ahead of time to avoid a violent confrontation with protesters. Recognizing that different local law enforcement agencies respond differently to tactics became an important part of planning protests for activists. After the Civil Rights era, many social movement participants intentionally sought arrests as a way of drawing attention to their particular movement, and the negotiated management policing strategy often included ritualized and sometimes scripted arrests. This history has led some members of the general public to equate arrests and willingness to risk arrest with protester militancy.

Black Lives Matter protesters I observed similarly challenged police but sought to avoid arrest. In order to do this, they too anticipated police responses to their behaviors but did so while trying to minimize the possibility of a serious altercation with police under new repression regimes that tolerate protest. In addition, in contrast with most 
recent research on protest policing, my findings show that police response to protesters' actions are more dependent on local police control norms than on tactics. For example, I find that the same level of disruptiveness can result in arrests in one city and not in another.

However, tactics were still important in the case of the protest events I observed, because they were purposeful and calculated in order for local movements to demonstrate that communities can police themselves. A focus on interactional resistance allows researchers to understand how activists' expectations for police during protests are central to how they dramatize their movement objectives.

\section{Methods and Data}

\section{The Importance of Place}

This study focuses on Black Lives Matter protest activity in two cities. These local contexts differ significantly in the policing practices that protesters encounter and operate within.

The first is College City, where police have a low-aggression stance towards protesters and engage in policing that closely resembles the negotiated management control style. College towns are usually more permissive of protesting and gentler in their interactions with students (McCarthy, Martin, and McPhail 2007). In contrast, Big City, in its policing has historically relied on arresting protesters for low-level infractions due to implementation of policies that enact a harsh response, placing it somewhere between escalated force and negotiated management. The policing of protests in Big City is more confrontational in its style of protestor control. Research on protest activity in Big City 
suggests that instances of arrests and use of force have increased over the past forty years despite a decline in confrontational actions by protesters.

Additionally, Big City's population is approximately thirty times the size of College City's. Thus, some of the distinctions between the policing of both cities can also be explained by police resources and population size. Big City has approximately 2.5 times more officers for every 1000 people in comparison to College City. Big City has the sheer capacity to control protests at a greater level.

There are also discernible racial demographic differences between the two cities. Big City is markedly more racially diverse than College City - the percent of the population that is Black or Latino is approximately four times as large. Similarly, the share of white officers in the police force in Big City is smaller than in College City. Black and Latino officers make up forty two percent of the police force in Big City and only seventeen percent in College City. Despite the racial differences in the populations, the racial and economic demographics of protesters in both cities were fairly diverse with protesters being more racially diverse in Big City due to racial population demographic differences. The economic demographics of the general populations also are much more similar with the median household income being in the high 50,000's in both cities. College City and Big City have close to twenty percent of their residents living in poverty.

Protester-police interactions in both cities were distinctive from each other with protesters in College City enacting a more transgressive approach at times. I hypothesize that this is partially because College City organizers favored the dramaturgical form of activism to make their claims. They may have felt more comfortable using such tactics. 
Because College City is a smaller community, organizers were sometimes familiar with the police officers charged with monitoring their protests, meaning that this may have given them greater leverage to negotiate in comparison with protesters in Big City who did not personally know the officers policing them. Further, police in College Town have rarely had to confront violent demonstrations in contemporary times while police in Big City have had to do so. This difference constrains police's perceived range of responses to transgressive protest activity in Big City—making it much less likely that they will be permissive of such tactics. In recent history in Big City, police and protesters' interests have often been diametrically opposed. In contrast, there have been times in College City when police and protesters' interests have aligned. This history and local culture can help explain variation in protester-police interactions across both cities.

Della Porta and Reiter (1998) argue that researchers cannot understand the relationship between police and protesters without also considering the political regime and circumstances external to the protest within which the protest takes place. Scholarship on policing also highlights the role of discretion and demonstrates how police departments can be entities in their own right, with some degree of independence from state actors (Marx 1998). Past research (Della Porta and Fillieule 2004; Earl and Soule 2006) suggests that the structure of local police departments, including staffing and orientation towards professionalism, are also important for considering police responses to protests, as well as have an impact on the police's knowledge and their stereotypes of protesters.

Recent qualitative scholarship on protest policing documents major protests that have received media attention and focuses on large metropolitan areas such as New York 
City, Seattle, and Washington D.C (Gillham, Edwards, and Noakes 2012; Gillham and Noakes 2007; Noakes, Klocke and Gillham 2005). However, there are also many smaller cities where smaller scale social movement activity occurs regularly and police may not respond to such protests with massive disruptions or repression. It is important that research not over-generalize about protest-police interactions from too few cases. Local police forces have different histories and relationships with protesters, depending on place, which influences both protest tactics and police responses to them. Thus, what it takes to be resistant looks somewhat different in each place. In Big City, less transgressive tactics appear more resistant because the threshold for arrest is lower, while in College City more transgressive tactics were needed to appear resistant because arrest was unlikely.

These two cases are valuable because they not only allowed me to observe a range of policing norms but also a spectrum of social movement activities occurring from large scale demonstrations to smaller, flash protests.

Focusing on a range of movement activities overtime in two different cities allowed me to gain a more comprehensive understanding of what every day protester activity and reaction to social movement repression looked like even during the moments when police were absent. I argue that protesters' interactional resistance is predicated on protesters' knowledge about the policing styles used by local authorities. Protesters figure out ways to enact resistance within their local regimes - breaching rules and laws at times and, at other times, taking care to stay within the bounds of rules and laws.

\section{Methods}


Data for this study were collected over the course of seven months through participant observation of two local Black Lives Matter movements. I participated in protests by following organizers' instructions, but I was never a leader, nor did I plan them myself. Throughout the paper, when I refer to protesters as "we," I am referring to the actions of the groups I participated in, but I am not implying that I made any organizing decisions myself.

First, over a period of five months, I attended bi-monthly protest events in College City. For my analysis, I draw primarily from fourteen first-hand observations at protests and movement events at county government meetings, as well as second-hand data collection from video footage of community meetings with College City's police department. The second phase of my fieldwork took place in Big City where I attended six protest events over the course of two months. I conducted approximately forty-two hours of data collection in College City and eighteen hours in Big City. In total, this research is based on twenty separate first-hand observations that lasted from two to four hours each.

In both cities, I conducted fieldwork in different settings and locations to produce a more comprehensive picture of the movement and political landscape including at protests, community and organizing meetings, county government meetings, and panel sessions with political and legal actors. Some of the events and meetings observed provided background knowledge for the research but this paper draws primarily from a subset of protests observed in both cities.

I recorded in-situ jottings during movement events and then wrote up longer fieldnotes that same day. To analyze my fieldnotes, I used an abductive approach 
(Timmermans and Tavory 2012). In line with the Chicago tradition of ethnography, I paid specific attention to the interactions emerging from my fieldnotes and took up the approach similar to that described by Robert Emerson (2009) in his call to ethnographers to investigate the "troubles" experienced by people in a particular setting.

Data for this study were collected from the protesters' perspectives, but the findings contain suggestions regarding the police's interactional resistance orientation as well through an examination of how they too manage and respond to the protesters' actions.

Drawing from my fieldwork, this study pays particular attention to direct actiona phrase used by the protest organizers for acts of civil disobedience — engaged in by demonstrators. Direct action involves behavior and activities that may often be defined as being illegal—occupying spaces, blocking traffic, marching in street traffic. In the midst of these actions, there exists high potential for tense interactions involving police and protesters to occur or for police to make arrests. Police often consider this type of action to be disruptive as it can unsettle the typical flow of urban life. However, these disruptions are the very reason that organizers choose to engage in direct action in the first place - the purpose of disturbing the everyday workings of the city is to make a statement about the racial injustice being brought upon protesters by the city and ultimately, the state.

\section{Findings}

\section{Enacting Civil Disobedience in College City}

One afternoon in January, 2015, I attended a protest with about twenty-five participants in College City. Without alerting police beforehand, we walked into the 
middle of a busy thoroughfare outside of a county government building and obstructed vehicle traffic for several minutes. The act of blocking traffic without facilitation by law enforcement is not only illegal, but carries considerable risk in terms of personal safety and arrest.

Several adults and children participating in the demonstration stood on the sidewalk, appearing to not want to take any potential bodily risks by walking into the middle of the street. The cars began to honk soon after we walked into the middle of the street and the pedestrian light turned to red. A man sitting in a vehicle in front of the protest line poked his head outside of the driver seat window. He subsequently started to yell at the protesters, moving his car dangerously close to the protesters, so close that its bumper was nearly touching a female protester. One of the protesters began a heated argument with a driver. After a few minutes, we walked out of the street and back onto the sidewalk.

Protesters were cognizant of the interactional bounds set in place by the police and motorists. They actively pushed back on them, while also staying within certain constraints. Organizers strategically molded their behavior in a way that allowed them to enact civil disobedience and yet, they also knew to leave the middle of the street after the light switched back to green. They stood in the street for only about three minutes, as they recognized that if they stayed in place any longer they would be risking arrests.

College City's police department confirmed this risk several days later at a community meeting. Although the police had not been present at the demonstration, a representative spoke about it and the protesters' use of confrontational tactics saying that protesters could have been met with legal repercussions for their tactics. College City 
police often allow protesters to disrupt normal traffic flow but want to be warned so they can deploy police to block traffic temporarily or divert traffic to alternate routes.

Protesters actively rebelled against the police's rules of engagement by not telling them about this action beforehand. Protesters did not act in the way the police department expected them to behave, considering local, prevailing negotiated management norms. They refused to engage with the police on their terms. In this way, they performed interactional resistance.

The police department described the protesters' actions as unplanned even though this was hardly the case from the protester perspective. Protesters acted outside of the police's expectations for them and prevented the police from managing their behavior. The police department emphasized that they would have allowed protesters to engage in this action if they had only alerted them beforehand. However, from the protesters' perspective, notifying the police would have defeated the motivation and purpose behind their protest. Furthermore, protesters knew that one of the police department's goals was to reduce the disruptiveness of this sort of confrontational tactic.

Thus, if protesters want to participate in confrontational tactics it does not make much sense to alert police to their plans beforehand, since they are well acquainted with the police's opposition towards this style of confrontational, disruptive protest. Disobeying laws is a purposeful component of how protesters challenge policing norms in College City. Some protesters disapprove of actions in which permits for occupying spaces are sought beforehand, as is required by College City's police department's rules. Protest permits are viewed as defeating the intended purpose of interactional resistance, 
since it gives the power over to other parties (i.e. the police) to set the terms of engagement.

When protesters strategically choose to resist negotiated management tactics with the police it is more likely they will be met with arrests or disapproval, even within local political structures that are more permissive of confrontational tactics. In this way, protesters actions are contingent on their understanding about the local rules of policing in their city. Ultimately, protesters stayed within certain boundaries in order to minimize costs, like arrest and loss of support from other protesters. For example, protesters-like myself-were not necessarily aware that we would be walking into traffic. We had not prepared to be arrested on this day. By leading people into traffic for only brief period of time, organizers avoided the risk that other protesters would not want to join in on their action because they feared police repression.

Protesters enacting this type of resistance also walked a fine line between being taken seriously by the public and still rebelling against the public order. This type of confrontational tactic can result in legitimacy issues as it interrupts drivers' daily routines. When drivers unknowingly crossed paths with protesters during this action, some of them were irritated by the interruption. However, from the protesters' standpoint, this reaction is exactly why they chose to stop traffic unannounced-because it makes a statement and drivers are forced to have their daily routine disrupted for several minutes.

While protesters in College City often abide by certain interactional terms set by the police, they are likely to find other outlets for resistance during the heat of protests. For example, they may announce beforehand the time and location at which a protest will occur and secure a permit for the protest, but will deviate from the police-endorsed 
activities. This was the case at a large rally that occurred in the aftermath of a Black teenager's death by a police officer in College City. Around 800-1000 people marched on sidewalks from a local park. Police were there to facilitate the march and had coordinated with the protest's organizers. However, at one point during the rally, a small group of protesters broke off from the main crowd, walking into the middle of the street to stop traffic for several minutes. In this way, the protesters delicately moved past the boundaries of police's rules of engagement, even though they generally sought to stay within them.

Even though police at this rally were cooperating with it in the style of negotiated management, protesters still found small ways to dramatize their desire to oppose police or to refuse to interact. For example, in addition to the police who were present at the rally, marshals assisted in facilitating the protest. These marshals were not hired by law enforcement; rather they were citizens attached to the groups organizing the protest.

During many demonstrations in College City, organizers prepared and distributed fliers that advised protesters on who to call and how to proceed in the event of a police arrest. During one march I attended for which planning had begun months before, there was a police liaison, appointed by organizers as a mediator between police and protesters, as a well as a legal team on call. Organizers advised protesters to download applications to their mobile phones, such as CopWatch, in the case of arrests. These applications record interactions with police and then automatically upload the footage to YouTube. Both in College City and Big City, legal observers trained by American Civil Liberties Union or National Lawyers Guild often marched alongside protesters to help facilitate their safety. 
Although in some protest movements, these types of actors are examples of how movements may try to cooperate with police, during the protests I observed the protesterappointed marshals as well as these other types of trained citizens became living, breathing examples of how communities could police themselves, dramatizing the larger motivation behind the resistance. Organizers tried to emphasize through these actors that movement participants could control themselves and did not need the police to interfere in their activities.

During protests, organizers in College City often explicitly instructed protesters not to interact with law enforcement policing the protests in order to avoid confrontations which could potentially escalate into arrests. They often resisted the police's terms of engagement by avoiding interactions with them altogether. Furthermore, avoiding the police helped to reduce the chance that law enforcement would use protesters' interactions with them to depict protesters in a negative light. Protesters were very aware of their negative depictions in the media and worked to prevent law enforcement from using confrontations with them to their advantage.

Police and protesters sometimes came to a consensus regarding rules of engagement. For example, I observed an instance where police gave organizers the power to de-escalate a highly tense police-protester confrontation.

This occurred at a march the day after the shooting of the Black teenager by a police officer in College City. The march ended in front of the victim's home, the place where the teenager had been shot. Protesters were impassioned and upset. They faced a group of police officers standing in front of the house and demanded answers for the teenager's death. The police blocked off three houses — including the teenager's — with 
yellow caution tape. Police officers stood outside the house with neutral facial expressions and gave little if any verbal response to the protesters' questions. People demanded to know the name of the officer who shot the young man even though his name had already been released to the public.

A visibly upset female protester yelled at a male police officer, castigating him for the young man's death. The protester's voice became increasingly loud, as she screamed at the officer. A fellow protester pulled her away.

Protesters began to become more agitated as they realized the police were blocking the view of the teenager's blood that was still stuck to the outside of his house. A young man - a protester- hopped over the yellow caution tape and tried to place roses in front of the house. The police approached him in an attempt to move him away from the house. He shouted as the police attempted to move him, leading several protesters to intervene. These protesters inserted themselves between the young man and the police, successfully pulling him away from the house and back behind the yellow tape.

In this moment, protesters worked with the police to de-escalate a highly tense situation. When the young protester breached the police tape, organizers of the march intervened to retrieve him, while also protecting him from a possible arrest. The police also refrained from arresting him or the protesters who intervened despite a tussle that might have otherwise resulted in arrest. Police allowed protesters to intervene in this situation and gave them the power to de-escalate. In this way, both protesters and police went outside of their differing bounds of interactions and found a middle ground that worked for them both. In this case, the College City police's negotiated management 
style permitted the police to cooperate with the protesters while the protesters to demonstrate their capacity for self-regulation.

\section{Protesting Alongside the Police in Big City}

Police in Big City have a distinctly more confrontational style of dealing with protesters than police in College City. On the one-year anniversary of a Black man's death at the hands of a police officer in Big City, protesters gathered at a busy pedestrian circle. A heavy police presence greeted us. A pre-recorded announcement by the police boomed, notifying protesters that obstructing traffic was illegal, despite the fact that protesters were gathered on the sidewalk. The recorded announcement, on continuous repeat, obscured speeches made by the protest organizers, and people in attendance began to grumble out of frustration.

"Turn that shit off!" A man remarked angrily.

About twenty minutes later, before we began to march, an organizer told us over a loudspeaker that if we were not comfortable being arrested or if we were already in any precarious legal situation then we should stay at the back of the march.

The loudspeaker announcement indicated that organizers had broadly formed their expectations for police behavior and responses to their actions. This shaped their subsequent planning and tactics. Their strategy emerged in a way that allowed for confrontational tactics to still take place, even if not every protester was willing to risk arrest.

As we began to march on the sidewalks, multiple fleets of police stood in the streets watching us. Some rode along on motorcycles. Two officers stood on a street 
corner outfitted in riot gear-helmets on, batons out of the holsters and in their hands. Unlike protests in College City, the sight of police officers holding multiple sets of plastic handcuffs is ubiquitous at protests in Big City. Experiencing police intimidation is often a critical component of the protester's reality. Also, in contrast with College City, arrests for walking in the middle of the street in Big City during protests are not uncommon and so protesters can easily strike up interactional resistance by walking into the middle of the street. This same action does not usually lead to arrest at marches in College City, thus interactional resistance takes on a different face depending on the local context.

Many Big City protesters that I observed are well aware of this type of confrontational police response to their activities and plan their behaviors in ways that both push back on constraints placed upon them while also often trying to avoid arrest. They try to strike a delicate balance between engaging in interactional resistance and not losing their freedom. This is what occurred during a flash protest I participated in with about fifteen other people one evening. Protesters walked through an upper middle class residential neighborhood. We stopped every so often - anywhere from one minute to seven - in front of traffic in the middle of the streets, raising signs and reading off facts about a Black transgender woman who died in police custody.

The unrehearsed, impromptu nature of the protest—stopping traffic for different amounts of time on various streets - was purposeful in that it allowed for the protesters to make disruptions but to still avoid arrests. The only time we were approached by police was when we began to walk into the middle of the street across from a police precinct office. This was the height of interactional resistance. A police car drove up to us, with 
lights turned on, as a voice projected through a megaphone told us that we must clear out from the middle of the street. There was a moment of hesitation when we waited in the middle of street, testing how far we could push the limits of this confrontational tactic without a serious interaction occurring between the police and us, resulting in our arrests. However, ultimately not wanting to risk arrests, protesters met with police on their terms - slowly dispersing and moving onto the sidewalk. We read facts out loud about the woman who died from our new position now in front of the precinct.

In some regard, police were more permissive of the protesters' tactical choices during this moment of hesitation than they may have been at another time. They did not race to make arrests, but rather gave us warning, waiting for us to disperse from the middle of the street. The lack of attention to us by police until this moment was most likely due to the small size of the group and because we were in a mostly white, residential neighborhood where there is already less regular police presence than other parts of the city. It should be noted that during other moments of disruptive actions organized by this group police have made arrests of protesters.

Police often expect that protesters will respect their authority and abide by legal codes of conduct. However, they are also aware that not all protesters, especially at large demonstrations, will abide by the rules of engagement, especially when it pertains to not walking in the middle of the street. In these instances, the police will not hesitate to arrest people who violate these engagement terms. Big City police demonstrated their readiness to make arrests during a protest that occurred in response to demonstrations surrounding the death of a Black man in police custody. Police arrested over 100 people according to a newspaper report the following day, citing people who chose to march in the street. 
People report being unfairly targeted for arrest, for reasons including race, even when they did nothing wrong. Nevertheless, protesters in Big City also understand that they are more likely to be repressed if they engage in confrontational tactics, indicating their understanding about the rules of the game concerning local policing practices. However, these rules do not stop them from trying to reject the bounds of social control through participating in civil disobedience. Interactional resistance looks different in Big City than in College City given the contrasting policing styles. It is important to consider what this means then for the concept of interactional resistance. For instance, in Big City, in contrast with College City, organizers are less explicit in advising protesters to not interact with the police and ready to accept that being arrested is just part of what they may have to face when they participate in demonstrations. This is part of the protester knowledge in Big City.

\section{Interactional Resistance within the Halls of Government}

Interactional resistance is not confined to the streets. Activists engage in interactional resistance at committee meetings and town halls, turning public meetings into sites of protests. Their resistance takes us back to College City. In the same way that protesters on the street push back against the police, activists at public hearings engage in interactional resistance and use tactics to push back against state control over their behaviors. The county government, in turn, attempts to control their behavior, calling into question the protesters' legitimacy.

At a public county government meeting attended by protesters, a protester walked into the middle of the room where the committee sat around a round table hearing public 
comments. The protester stood at the front of the room facing towards the public audience and other protesters. A committee member told her that she was not permitted to stand facing the public.

The protester expressed dissatisfaction with this request while at the same time indicating that she knew how meetings were usually run. The committee member repeated to the protester that that she was not permitted to stand that way. The protester knew her behavior was not in line with how most other people usually gave comment during the county meetings. She was aware that there was a set code of conduct that existed for these meetings as evidenced by the conversation. However, she desired to push back on the bounds.

The lead committee member became visibly annoyed with the protester. The protester then commenced a conversation with the committee about her ability to stand facing the public. The committee attempted to manage the protester's behavior because she was refusing to abide by the committee's rules of engagement. They did not want her to stand facing the audience or use activist rhetoric.

The protester, not wanting to risk relinquishing her moment to speak at the meeting, ultimately decided to abide by the board's norms and turned around to face the committee during her comments. In this way, she attempted to predict and control their response, while still enacting somewhat confrontational tactics. The committee member eventually interrupted the protester's comment, indicating that her time for speaking had expired.

Much of the protester's behavior was a purposeful part of how she was conducting herself as an activist leader. The act of facing the audience was done in order 
to connect with other protesters. This was part of her interactional resistance as she tried to make a statement of her disproval for the state and its role in mass incarceration.

The committee member commented on her speech as a kind of eruption and attempted to cut her off from speaking after three minutes. Thus, the committee member worked to place restrictions on the protester and drew boundaries around what was acceptable and what was not. Aspects that fulfilled the protester's role as an activist were ultimately deemed unacceptable.

On another occasion at the same meeting, the committee member asserted that the audience was not allowed any audible responses since that would violate the rules. He declared that the audiences' responses extend the length of meetings. He also told the public not to hold their protest signs, which they purposefully brought as an additional way of resisting the terms of engagement. Again, through these pronouncements, the county government drew temporal, physical, and normative boundaries around what was considered appropriate behavior for people participating in the movement. In this way, it sought to manage the movement's behavior in light of their participation in interactional resistance. However, protesters still found new ways to subvert the county's challenges through their words.

\section{Violations of the Social Order}

Interactional resistance shares many similarities with other forms of protest tactics. However, it is distinctive in joining an intention to express resistance to police authority with a desire to avoid arrest. In interactional resistance protesters walk a delicate line in trying to evade police control while also maintaining their freedom. It is a 
distinctive type of tactic that is performed under policing regimes that tolerate protest. It is different from protests seeking arrest, and different from protests that are likely to be met with violence by police or others, as was common for Civil Rights protesters (Morris 1984; Morris 1993) and for protesters meeting escalated force policing in the 1960s. The rules of the game for both protesters and police have evolved over time since the Civil Rights Movement and the 1960s.

Interactional resistance is also different from other forms of political resistance in that not all forms of resistance tactics map directly onto a movement's aims nor involve "face-to-face interaction" between protesters and their targets (Taylor and Van Dyke 2004). Black Lives Matter protesters through dramaturgy tactics sought to show the police and others that communities can be autonomous and self-policing. Thus, in this specific situation when the goal is to make the claim that communities do not need police to maintain their safety, it makes sense that protesters would want to dramatize such point while doing all that they can to avoid provoking violence or needing the police to intervene in their activities. The Black Lives Matter movement is a particularly good case for examining interactional resistance because protesters' responses to policing at protests are a critical strategy for displaying the movement's ultimate goal of transformation of the country's criminal justice system.

However, the concept of interactional resistance developed in this article can apply to other interactional contexts that involve a power imbalance between groups of people. Ethnographic work and work in the Symbolic Interaction tradition has also paid close attention to the ways that people violate the conditions of social interaction and the public order. Examining protesters' interactional challenges, together with these other 
interactions between subordinate and dominate groups, allows us to better understand how small acts of resistance in the literature - though on their face non-political acts-are an effort to subvert prevailing ways of being in the social world.

For example, scholars such as James Scott (1985), Elliot Liebow (1967), Mitchell Duneier (1999) write about the everyday forms of resistance enacted by peasants, poor people, and homeless men-individuals who usually do not the possess the power to participate in organized political rebellions. Mitchell Duneier and Harvey Molotch (1999) in their analysis of conversations that unhoused men have with middle class women on the sidewalks of New York City, argue that these men violate the interaction order when they hit on women on the street. The men continue to speak, even doing so as many seconds pass without receiving a response from the women, while ignoring social cues that the women do not want to talk them. Other examples in these works include when people fail to show up to work, steal from their employers, or use the bathroom in the street in the absence of having somewhere else to go.

Violations of the interactional order need not be overt or purposeful. Erving Goffman (1963) writes that when people simply embody characteristics that make them lesser in the eyes of society-displaying some gap between how society expects them to appear and how they actually appear-this spoils the course of an interaction. Society may discriminate, label, or attribute additional flaws to them. Stigmatized people then in turn must manage how others receive them.

Violations may be an unavoidable act for some, but a purposeful one for others. Homeless and stigmatized people face circumstances that make them physically unable to follow the rules of the interactional and public order (Duneier 1999; Goffman 1963). 
Meanwhile, for individuals who rebel against their employers, violations may be subtle acts of subversion that provide some momentary satisfaction, even if society ultimately penalizes them for engaging in them (Liebow 1967; Scott 1985). In the case of men who hit on women, they may be deliberate acts to trick or manipulate the interaction (Duneier and Molotch 1999). These transgressions often go unnoticed or unacknowledged as forms of resistance. However, to the extent that they are efforts to subvert the terms set by society's dominant groups, they too are forms of interactional resistance.

\section{Conclusion}

This article has argued that interactional resistance is a key protest strategy of local Black Lives Matter movements. Focusing on interactional resistance allows social scientists to better comprehend the implications of contentious moments when protesters in this study look for ways to enact legitimate civil disobedience tactics, while still overwhelmingly trying to avoid arrest and violence. Protesters today, similar to the Civil Rights Movement, still try to find ways to resist police; however, they do so in a new historical moment and under new repression regimes. The findings of this study add new contributions to the literature on protester-police relations through 1) examining distinct kinds of protest activities overtime in two differing locations with different sizes and policing regimes; 2) shifting the focus onto protesters' decisions and the structural knowledge needed to accomplish resistance in relation to repression in lieu of only focusing on the police and the state; 3) analyzing how the potential for police presence at demonstrations shapes protesters' tactics and how protesters accomplish resistance even in the moments when police are absent, do not make arrests, or the probability for arrest 
is low; 4) showing that depending on the local protest context, police may in fact be more or less permissive of civil disobedience independent of how "transgressive" protester tactics are.

Protesters' subversion of the terms of engagement set by the police draws on their knowledge of the norms behind local policing. Repression in Big City or College City was not as obvious as it was in Ferguson, Missouri, where police were unmistakably armed with rifles and tear gas in the wake of protests surrounding Michael Brown's death (Bloom and Frampton forthcoming). However, this contrast also emphasizes the need to pay attention to the more insidious actions taken to control social movement activitieswhether that be drowning out the sounds of protest with pre-recorded police announcements or outlawing the use of protest signs at county meetings.

At protests and public hearings, the goals of ending mass incarceration, police misconduct, and the devaluing of Black lives are enacted and embodied in activists' interactional resistance to the police's terms of engagement. This interactional resistance to the police also embodies the tenet that Black communities can and should police themselves. These intentional moments are not only fundamental to the architecture of these historic local movements, but also to people's tactics for fighting against police violence. They also depend on protesters being able to anticipate police responses to their behavior and incorporating these responses into their tactics as they try to find ways to resist interactional norms with the police without going too far. It is critical for movement success that protesters do not completely skirt these boundaries of engagement and that protests stay non-violent in order for protesters to convincingly make the claim that communities can police themselves. 
Interactions between protesters and law enforcement can say much about movements themselves, not only limited to how movements are controlled by authorities. Typologies and variables behind police responses and protester tactics are important for understanding social movements but they do not mean much without also considering how protesters themselves often at once resist and comply with police orders.

In future work, scholars could examine the emergence of interactional resistance on a national level, arising in the form of protesters' resistance on social media and the public's reaction to this resistance. Additionally, an interactional resistance framework could be applied to examine people's growing use of cellphones to record problematic interactions with police, which occurs inside and outside of social movements.

Researchers should also be mindful of the structural aspects embedded in this unequal relationship — ultimately police carry more power and force than protesters. Protesters risk their freedoms through arrest and at times, their lives. However, without drawing from ethnographic data, scholars can easily ignore interactional nuances that underpin protesters' objectives and responses to repression in current social movements. 


\section{Works Cited}

Benford, Robert and Scott A. Hunt. 1992. "Dramaturgy and Social Movements: The Social Construction and Communication of Power." Sociological Inquiry 62(1): $36-55$.

Benwell, Bethan and Elizabeth H. Stokoe. 2002. "Constructing Discussion Tasks in University Tutorials: Shifting Dynamics and Identities.” Discourse Studies 4(4): $429-53$.

Bloom, Joshua and Zachary David Frampton. Forthcoming. "Racist Policing, Practical Resonance, and Frame Alignment in Ferguson." In Racialized Resistance and the State: Protest and Repression in Trumpian America, edited by Hank Johnston and Pamela Oliver.

Braunstein, Ruth. 2018. "Boundary-Work and the Demarcation of Civil from Uncivil Protest in the United States: Control, Legitimacy, and Political Inequality." Theory and Society 47(5): 603-633.

Clayman, Steven E. 2001. “Answers and Evasions." Language in Society 30(3): 403-42.

Davenport, Christian, Sarah A. Soule, and David A. Armstrong. 2011. "Protesting While Black? The Differential Policing of American Activism, 1960 to 1990." American Sociological Review 76(1): 152-78.

Della Porta, Donatella and Mario Diani. 2006. Social Movements: An Introduction. Oxford, UK: Blackwell Publishing. 
Della Porta, Donatella and Olivier Fillieule. 2004. "Policing Social Protest." Pp. 217-41 in The Blackwell Companion to Social Movements, edited by D. A. Snow, S. A. Soule, and K. Hanspeter. Oxford, UK: Blackwell Publishing.

Della Porta, Donatella and Herbert Reiter, eds. 1998. Policing Protest: The Control of Mass Demonstrations in Western Democracies. Minneapolis, Minnesota: University of Minnesota Press.

Duneier, Mitchell. 1999. Sidewalk. New York City, New York: Farrar, Straus and Giroux.

Duneier, Mitchell and Harvey Molotch. 1999. “Talking City Trouble: Interactional Vandalism, Social Inequality, and the 'Urban Interaction Problem."' American Journal of Sociology 104(5): 1263-95.

Earl, Jennifer. 2003. "Tanks, Tear Gas, and Taxes: Toward a Theory of Movement Repression." Sociological Thoery 21(1): 44-68.

Earl, Jennifer, Sarah A. Soule, and John D. McCarthy. 2003. "Protest under Fire? Explaining the Policing of Protest." American Sociological Review 68(4): 581606.

Earl, Jennifer. 2005. "You Can Beat the Rap, But You Can't Beat the Ride: Bringing Arrests Back into Research on Repression.” Pp. 101-39 in Research in Social Movements, Conflicts and Change, vol. 26, Research in Social Movements, Conflicts and Change. Bingley, UK: Emerald Group Publishing Limited. 
Earl, Jennifer and Sarah Soule. 2006. "Seeing Blue: A Police-Centered Explanation of Protest Policing." Mobilization: An International Quarterly 11(2): 145-64.

Emmerson, Robert M. 2009. "Ethnography, interaction and ordinary trouble." Ethnography 10(4): 535-548.

Gillham, Patrick, Bob Edwards, and John A. Noakes. 2012. "Strategic Incapactitation and the Policing of Occupy Wallstreet Protests in New York City, 2011." Policing and Society 23(1): 81-102.

Gillham, Patrick and John Noakes. 2007. “"More Than A March in a Circle’: Transgressive Protests and the Limits of Negotiated Management.” Mobilization: An International Quarterly 12(4): 341-57.

Goffman, Erving. 1959. The Presentation of Self in Everyday Life. New York City, New York: Random House.

Goffman, Erving. 1963. Stigma: Notes on the Management of Spoiled Identity. New York City, New York: Simon and Schuster.

Hollander, Jocelyn A. and Rachel L. Einwohner. 2004. "Conceptualizing Resistance." Sociological Forum 19(4): 533-554.

King, Mike. 2013. "Disruption Is Not Permitted: The Policing and Social Control of Occupy Oakland.” Critical Criminology 21(4): 463-75. 
Larson, Jeff A. 2013. "Social Movements and Tactical Choice." Sociology Compass 7(10): 866-79.

Liebow, Elliot. 1967. Tally's Corner: A Study of Negro Streetcorner Men. Boston, Massachusetts: Little, Brown and Company.

Marx, Gary T. 1998. "Some Reflections on the Democratic Policing of Demonstrations." in Policing Protest: The Control of Mass Demonstrations in Western Democracies, edited by D. D. Porta and H. R. Reiter. Minneapolis, Minnesota: U of Minnesota Press.

McCammon, Holly J., Soma Chaudhuri, Lyndi Hewitt, Courtney Sanders Muse, Harmony D. Newman, Carrie Lee Smith, Teresa M. Terrell. 2008. "Becoming Full Citizens: The U.S. Women's Jury Rights Campaigns, the Pace of Reform, and Strategic Adaptation." American Journal of Sociology 113(4): 1104-47.

McCarthy, John D., Andrew Martin, and Clark McPhail. 2007. "Policing Disorderly Campus Protests and Convivial Gatherings: The Interaction of Threat, Social Organization, and First Amendment Guarantees." Social Problems 54(3): 274296.

McPhail, Clark, David Schweingruber, and John D. McCarthy. 1998. "Policing Protest In the United States: 1960-1995.” Pp. 49-69 in Policing Protest: The Control of Mass Demonstrations in Western Democracies, edited by D. D. Porta and H. R. Reiter. Minneapolis, Minnesota: U of Minnesota Press. 
Meyer, David S. 2007. The Politics of Protest: Social Movements in America. New York, New York: Oxford University Press.

Monzoni, Chiara M., Roderick Duncan, Richard Grünewald, and Markus Reuber. 2011. “Are There Interactional Reasons Why Doctors May Find It Hard to Tell Patients That Their Physical Symptoms May Have Emotional Causes? A Conversation Analytic Study in Neurology Outpatients.” Patient Education and Counseling 85(3): 189-200.

Morris, Aldon D. 1984. The Origins of The Civil Rights Movement. New York, New York: The Free Press.

Morris, Aldon D. 1993. "Birmingham Confrontation Reconsidered: An Analysis of the Dynamics and Tactics of Mobilization.” American Sociological Review 58(5): $621-36$.

Noakes, John, Brian Klocke and Patrick Gillham. 2005. "Whose Streets? Police and Protester Struggles over space in Washington, DC," September 29-30, 2001. Policing and Society 15(3):235-254.

Rafail, Patrick, Sarah A. Soule, and John D. McCarthy. 2012. "Describing and Accounting for the Trends in US Protest Policing, 1960-1995." Journal of Conflict Resolution 58(4): 736-765.

Reynolds-Stenson, Heidi. 2017. "Protesting the Police: Police Brutality Claims as a Predictor of Police Repression of Protest.” Social Movement Studies 17(1): 48-63. 
Scott, James C. 1985. Weapons of the Weak: Everyday Forms of Peasant Resistance. New Haven, Connecticutt: Yale University Press.

Snow, David A. 1979. "A Dramaturgial Analysis of Movement Accomodation: Building Idiosyncracy Credit As a Movement Mobilization Strategy." Symbolic Interaction 2(2): $23-44$.

Soule, Sarah and Christian Davenport. 2009. "Velvet Glove, Iron Fist, or Even Hand? Protest Policing in the United States, 1960-1990.” Mobilization: An International Quarterly 14(1): 1-22.

Taylor, Verta and Nella Van Dyke. 2004. “'Get Up, Stand up’: Tactical Repertoires of Social Movements.” Pp. 262-93 in The Blackwell Companion to Social Movements. Oxford, UK: Blackwell Publishing.

Timmermans, Stefan and Iddo Tavory. 2012. "Theory Construction in Qualitative Research." Sociological Theory 30(3): 167-186.

Uba, Katrin. 2005. "Political Protest and Policy Change: The Direct Impacts of Indian Anti-Privatization Mobilizations, 1990-2003.” Mobilization: An International Quarterly 10(3): 383-96.

Wang, Dan J. and Alessandro Piazza. 2016. "The Use of Disruptive Tactics in Protest as a Trade-Off: The Role of Social Movement Claims.” Social Forces 94(4): 16751710. 
